\title{
When long-term care comes to an end: informal caregivers' perspectives on patient discharge
}

Quando os cuidados continuados chegam ao fim: perspetivas de cuidadores informais sobre o momento da alta

Cuando los cuidados de larga duración terminan: perspectivas de los cuidadores informales sobre el momento del alta

Adriana Carvalho*iD; Lia João Pinho Araújo** iD ; Manuel Teixeira Veríssimo*** (D)

\section{Abstract}

Background: The purpose of long-term integrated care units is the readaptation and reintegration into family and social life.

Objective: To understand informal caregivers' perspectives on the discharge of their relatives with dementia from long-term care facilities.

Methodology: Fifteen caregivers (mean age of 60 years) were interviewed, and data were qualitatively analyzed using NVivo.

Results: Despite the concern and fear about discharge, most participants did not take any action. When questioned about what they would do if their family member was discharged from the unit, they mentioned that they would return home $(n=5)$ or go to a residential facility for older people $(n=10)$. This decision is justified by one or more reasons, namely environmental factors, caregiver unavailability, relationship of proximity, economic issues, and family issues.

Conclusion: Healthcare professionals should consider the reasons influencing the integration and delivery of patient care after discharge to better support, train, and empower informal caregivers. These measures should be part of a care routine.

Keywords: delivery of health care; caregivers; dementia; patient discharge

\section{Resumo}

Enquadramento: As unidades de cuidados continuados integrados (UCCI) têm como princípio a readaptação e reinserção familiar e social.

Objetivo: Conhecer as perspetivas de cuidadores informais sobre o momento da alta do internamento em cuidados continuados dos seus familiares com demência.

Metodologia: Quinze cuidadores (média de idades 60 anos) foram entrevistados e os dados analisados qualitativamente com recurso ao NVivo.

Resultados: Apesar da preocupaçáo e medo relativamente ao momento de alta, a maioria dos participantes não tomou qualquer ação. Quando questionados sobre o que fariam se o seu familiar tivesse alta da UCCI, referem considerar o domicílio $(n=5)$ ou uma estrutura residencial para pessoas idosas $(n=10)$. Esta decisão tem em conta um ou mais motivos, nomeadamente fatores ambientais, indisponibilidade do cuidador, relação de proximidade, questôes económicas e questôes familiares. Conclusáo: Os motivos que pesam na integração e prestaçáo de cuidados ao paciente após a alta devem ser considerados pelos profissionais, no sentido de um melhor apoio, formação e capacitação dos cuidadores informais, medidas que devem ser partes constituintes de uma rotina de cuidados.

Palavras-chave: assistência à saúde; cuidadores; demência; alta do paciente

*Degree. Master's student, Faculty of Medicine of the University of Coimbra, 3000-370, Coimbra, Portugal [adrifidalgocarvalho@gmail.com]. @ https://orcid.org/0000-0002-6045-4413. Contribution to the article: conduct and analysis of interviews and article writing.

**Ph.D., Adjunct Professor, Polvtechnic Institute of Viseu. Researcher, Center for Health Technology and Services Research (CINTESIS.UP), 4200-450, Porto, Portugal [liajaraujo@esev ipv.pt]. (1) https://orcid.org/0000-0001-8212-9235. Contribution to the article: study guidance, literature search, and article writing. Address for correspondence: Rua Maximiano Aragão, 3504-509, Viseu, Portugal.

***:Ph.D., Assistant Professor, Faculty of Medicine of the University of Coimbra. Specialist Coimbra Hospital and University Center, 3000-075, Coimbra, Portugal [mverissimo@fmed. uc.pt]. (1D https://orcid.org/0000-0002-2793-2129. Contribution to the article: study guidance

\section{Resumen}

Marco contextual: El principio de las unidades de cuidados de larga duración integrados (unidades de cuidados continuados integrados - UCCI) es la readaptación y reintegración familiar y social.

Objetivo: Conocer las perspectivas de los cuidadores informales sobre el momento del alta hospitalaria en cuidados de larga duración de sus familiares con demencia.

Metodología: Se entrevistó a 15 cuidadores (edad media de 60 años) y se analizaron los datos cualitativamente mediante NVivo.

Resultados: A pesar de la preocupación y el temor al momento de recibir el alta, la mayoría de los participantes no tomaron ninguna medida. Cuando se les preguntó qué harían si su familiar recibiera el alta de la UCCI, respondieron que considerarían el domicilio $(n=5)$ o una residencia para personas mayores $(n=$ 10). Esta decisión tiene en cuenta uno o más motivos, a saber, los factores ambientales, la falta de disponibilidad del cuidador, la relación de proximidad, las cuestiones económicas y las cuestiones familiares.

Conclusión: Los motivos que influyen en la integración y la prestación de cuidados al paciente después del alta deben ser considerados por los profesionales, con el fin de apoyar, formar y capacitar mejor a los cuidadores informales, medidas que deberían formar parte de una atención rutinaria.

Palabras clave: prestación de atención de salud; cuidadores; demencia; alta del paciente

Received for publication: 29.04 .19

Accepted for publication: 03.09 .19 


\section{Introduction}

The Portuguese National Network for Long-Term Integrated Care (Rede Nacional de Cuidados Continuados Integrados - RNCCI), which is focused on people with functional dependence, patients living with multiple chronic conditions or advanced incurable diseases, and end-of-life patients, has been playing a significant role in the formal care of people with dementia. It is an innovative service because it promotes the continuity of care in an integrated manner and involves the adapted and proactive work of healthcare and social support teams while engaging the patients and family members/informal caregivers (Unidade de Missão para os Cuidados Continuados Integrados, 2007). The Portuguese National Health Service has been increasing the investment in long-term care, and the number of inpatient beds has increased from 4,465 in 2010 to 8,553 in 2018 (Ministério da Saúde, 2019). Also, the number of outpatient and domiciliary settings has increased, in a total of 14,430 settings (Ministério da Saúde, 2019). Older people are the most significant group of long-term care users (85.5\%), and the dependence in activities of daily living and the education of patients/informal caregivers are the main reasons for referral (Administração Central do Sistema de Saúde, 2018).

These units provide convalescent, rehabilitation, and reintegration care to chronic patients and people in a situation of dependence aiming at their recovery, rehabilitation, and reintegration into family and social life. However, the end of hospitalization can be a challenge for many families and raise doubts as to the patient's return to his or her family and social environment. The objective of this study is to understand informal caregivers' perspectives on the discharge process of their family members with dementia from long-term care facilities.

\section{Background}

Portugal has been undergoing changes in the population age structure, particularly in the proportion of the group aged 60 years or over, which accounted for $27.9 \%$ of the total population in 2017 and is expected to increase to $41.7 \%$ by 2050 (United Nations, 2017).

Aging is a complex process that results from the interaction of biological, psychological, and social factors and involves somatic and psychosocial changes (Sequeira, 2010). Despite being considered a normative and universal process, events and transitions associated with advancing age, such as the loss of a spouse, family members or peers, or the loss of social status and network with the transition to retirement, are some of the challenges in this phase of life. However, for many people, aging is associated with the deterioration of the health status and loss of functional ability, often due to chronic and degenerative diseases with high morbidity and mortality rates and a significant impact on the use of healthcare services.

Neurodegenerative diseases are one of the major causes of the dementia syndrome, which leads to a progressive loss of cognitive abilities and memory, with an impact on functionality and autonomy (Santana, 2012). In Portugal, 2013 data indicate that 50 to $70 \%$ of the people living with dementia also had Alzheimer's disease (Santana, Farinha, Freitas, Rodrigues, \& Carvalho, 2015).

Due to the complexity of the most common symptoms in a dementia process, which include losses and changes in intellectual, functional, social, and emotional skills, dementia does not only affect the individual but also the lives of those around them and, (in)directly, society as a whole. Given the trend of population aging and, consequently, the increase in the prevalence of dementia in coming years, leading international organizations have identified dementia as a public health priority, calling attention to the need for appropriate interventions to meet patients' health and social needs and promote their autonomy, functional abilities, and self-determination (World Health Organization \& Alzheimer's Disease International, 2012).

Long-term integrated care units (Unidades de Cuidados Continuados Integrados - UCCI) have been playing an essential role in supporting people with dementia. In addition to rehabilitation and readaptation, their primary purpose is the reintegration into the family and social life (Unidade de Missão para os Cuidados Continuados Integrados, 2007). Thus they assume that informal caregivers must be considered in the care process, both as users and as partners. As users, because they also often require care and, as partners, because these non-professional caregivers need to be trained to provide better care (Ministério do Trabalho, Solidariedade e Segurança Social \& Ministério da 
Saúde, 2016). This makes even more sense in a country like Portugal, where the family is culturally regarded as being responsible for care delivery. But also as partners, to the extent that they can be important agents for effective achievements in the processes of readaptation and reintegration of people with dementia, thus putting into practice the assumptions of the RNCCI (Unidade de Missão para os Cuidados Continuados Integrados, 2007). However, studies on the health status and well-being of informal caregivers of people with dementia have, unanimously, reported worrying results. These caregivers are more susceptible to high overload levels, both in objective and subjective measures, primarily due to the difficulty in helping their relatives in their everyday tasks and managing and supervising problematic behaviors (Eloia et al., 2018). Sequeira (2010) adds that the different types of overload (physical, psychological, emotional, social, and financial) should be considered, as well as the poor quality of care delivery when they are not duly supported by formal care services. The burden to which the caregivers of people with dementia are subjected has a negative impact not only on their physical health but also on their psychological health, leading to higher levels of depression and anxiety that those found among caregivers of older people without dementia (Seeher, Low, Reppermund, \& Brodaty, 2013). At a social level, caring for people with dementia is associated with a higher incidence of family conflicts and lower support and social interaction (Etters, Goodall, \& Harrison, 2008). Psychoeducational and psychotherapeutic interventions are the most effective in improving caregiver burden, depression, subjective well-being, satisfaction, and ability/knowledge (Sörensen, Pinquart, \& Duberstein, 2002).

\section{Research questions}

What decision is made on the integration of people with dementia after discharge: in the community or in a residential facility? What are the factors that influence this decision?

\section{Methodology}

\section{Participants}

Based on an exploratory and qualitative ap- proach, this study used an intentional, homogeneous sample composed of family caregivers of people with dementia admitted to a UCCI, preferably a long-stay and maintenance unit (Unidade de Longa Duração e Manutenção ULDM) in the district of Guarda and Viseu. In a first moment, $20 \mathrm{UCCI}$ in these districts were contacted by phone and/or email. The UCCI selected potential participants based on their knowledge and privileged information about each case. Then, they established the first contact with the potential participants, informing them about the study, as well as the possibility and importance of their participation. The caregivers who agreed to participate were interviewed afterward.

Fifteen caregivers participated in this study because data saturation was reached, that is, interviewing more caregivers would not add any new information.

\section{Data collection}

An interview script was used. The script was composed of sociodemographic questions about the informal caregivers and open questions on the experience and opinion of informal caregivers of people with dementia admitted to long-term care units about their expectations for discharge. Anticipating the participation of older caregivers, possibly with low levels of education and problems of discourse interpretation and production, a set of additional questions were included, namely "At the time of discharge of your family member, what decision should be taken concerning care delivery?" and "What did you took/are you taking into account to make this decision?" The script was drawn up by the interviewer based on a literature review and the study objectives, and professionals working in long-term care settings with informal caregivers were asked to help assess the relevance and sensitivity of the questions for the interview. More specifically, two technicians specialized in psychology and social work read and gave their opinion about the script to make it as appropriate and complete as possible.

It was decided that the interviews would be individual and take place at a private location at the UCCI which indicated the participant and at a time chosen by the caregiver. The interviews were conducted in a single moment, which lasted on average 45 minutes. They were 
conducted by the same interviewer, a senior technician with experience in the area of intervention with older people and their families. Confidentiality and anonymity were ensured and foreseen in the informed consent form signed by each participant. Participants consented to audio recording of their interviews.

\section{Data analysis}

Data were analyzed and synthesized using the content analysis technique, in which, after a floating reading to capture the general sense of each interview for data approximation, the several conceptually valid thematic areas were identified and categorized based on content similarity. The topics that represented the same meaning were grouped into the same category, composed of subcategories and several indicators that represented recording units found in the text. The interviews were identified and coded by the same person who conducted the interviews and reviewed by an external researcher. NVivo software for qualitative analysis was used in for data coding and analysis.

\section{Results}

The 15 informal caregivers who participated in this study were aged between 22 and 80 years (Mean $-M=60 ; S D=16.64$ ), being mostly females $(n=10)$ and married $(n=10)$. The group was educated, ranging from the $4^{\text {th }}$ grade $(n=6)$ to the undergraduate degree $(n=4)$. As for their professional and occupational status, six of them were retired, four were employed, three were homemakers, one was a student, and one was unemployed. Concerning the type of relationship with the person admitted to the UCCI, six of the interviewees were spouses, six were children, two were granddaughters, and one was a niece (Table 1 ).

Table 1

Sociodemographic characterization of participants

\begin{tabular}{ccccccc}
\hline Age & Gender & Marital status & $\begin{array}{c}\text { Academic } \\
\text { qualifications }\end{array}$ & $\begin{array}{c}\text { Professional } \\
\text { situation }\end{array}$ & Relationship \\
\hline I1 & 60 & Female & Married & Degree & Retired & Daughter \\
I2 & 80 & Male & Married & $4^{\text {th }}$ grade & Retired & Spouse \\
I3 & 60 & Female & Married & $4^{\text {th }}$ grade & Employed & Spouse \\
I4 & 62 & Female & Married & $6^{\text {th }}$ grade & Homemaker & Daughter \\
I5 & 78 & Male & Married & $4^{\text {th }}$ grade & Retired & Spouse \\
I6 & 60 & Female & Married & $9^{\text {th }}$ grade & Unemployed & Daughter \\
I7 & 45 & Female & Divorced & Degree & Employed & Niece \\
I8 & 57 & Female & Married & $9^{\text {th }}$ grade & Homemaker & Daughter \\
I9 & 76 & Female & Married & $4^{\text {th }}$ grade & Retired & Spouse \\
I10 & 68 & Female & Married & $4^{\text {th }}$ grade & Retired & Spouse \\
I11 & 30 & Female & Single & $12^{\text {th }}$ grade & Employed & Granddaughter \\
I12 & 46 & Male & Single & $12^{\text {th }}$ grade & Employed & Son \\
I13 & 77 & Male & Married & $4^{\text {th }}$ grade & Retired & Spouse \\
I14 & 22 & Female & Single & Degree & Student & Granddaughter \\
I15 & 50 & Male & Single & Degree & Homemaker & Son \\
\hline
\end{tabular}

When asked about the moment of discharge of their relatives admitted to the UCCI, the participants found it very difficult to talk about this topic because they were afraid of this possibility and were even in denial. Some of the participants had already considered this possibility and took some measures, but the vast majority of them had not and were aware of it, as can be seen in the following examples: "I am aware of what can happen, but I don't anticipate that moment" (I3; February, 2017); "What? I don't want to think about it, no, no, 
I don't think about it. It's a disease, being like this for so long" (I13; October, 2017).

When asked about what they would do if their family members were discharged from the UCCI, two categories emerged from the interviews: return home $(n=5)$ and institutio- nalization $(n=10)$. Several reasons influenced this decision, namely environmental factors $(n=8)$; caregiver unavailability $(n=3)$; relationship of proximity $(n=5)$; economic issues $(n=2)$; and family issues $(n=3$; Figure 1$)$.

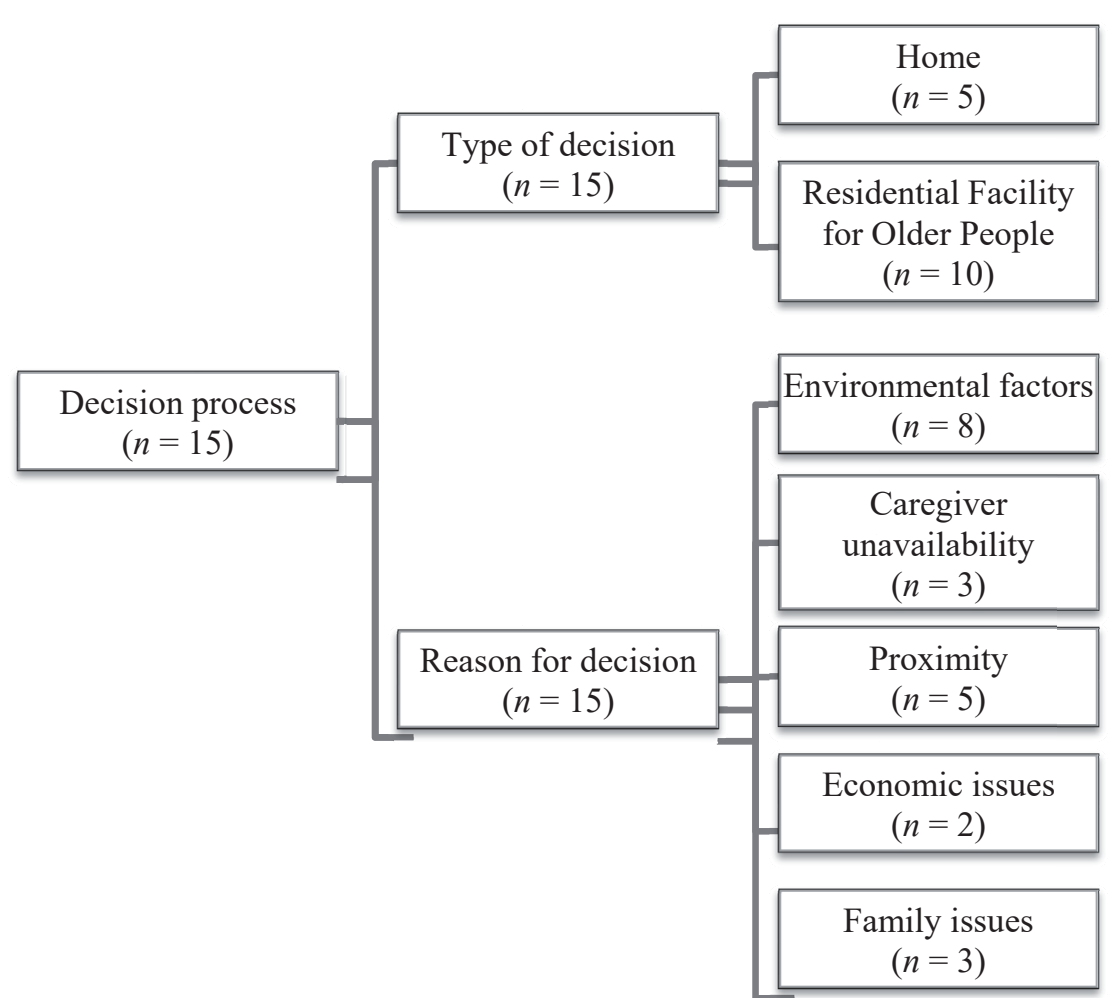

Figure 1. Aspects mentioned by the participants on their relatives' discharge after relationship of proximity.

These reasons are detailed in Table 2, in which it is possible to check the meaning attributed by the participants. The environmental factors influenced the decision because the participants reported that due to architectural barriers (e.g., stairs), transportation problems (e.g., lack of own car), and poor housing conditions (e.g., small areas where the person cannot move around) patients could return to their own homes or live with their informal caregivers. Other caregivers reported reasons related to their unavailability to provide a formal response because some of them were still working and had no other informal support. The family issues were also mentioned as reasons for con- sidering a residential facility, especially the conflicts between siblings or rejection within the household.

The caregivers who prefer the possibility of integration in the community, that is, the return home, emphasized aspects related to the relationship of proximity with their family member. The retribution of care, the respect for the family member's decision of not being institutionalized, but also the fact that the patient is not able to demonstrate his or her wishes were the most common situations. Moreover, the economic issues were also mentioned to the extent that formal care is costly and many of these formal settings have no vacancies. 
Table 2

Synthesis of the reasons influencing the type of decision - return home or integration into a residential facility

\begin{tabular}{lccc}
\hline Reason for decision & Sources & References & \multicolumn{1}{c}{ Example of Transcriptions } \\
\hline Subcategories & 8 & $\begin{array}{l}\text { "I have to climb } 40 \text { steps to get home, it is impossible to } \\
\text { take [him or her] home" (I1; January, 2017) } \\
\text { "if he returns home, what am I going to do, my house is so } \\
\text { far away from my father's house and I have no way to get } \\
\text { there" (I4; March, 2017) }\end{array}$ \\
\hline Environmental factors & $\begin{array}{l}\text { "I can't care for him at home and do everything alone with } \\
\text { my son ... from now on, I can't have him at the restaurant, }\end{array}$ \\
\hline Iaregiver unavailability & 3 & $\begin{array}{l}\text { I'll have to close doors" (I3; February, 2017) } \\
\text { "we could take him home, ok, but we would be overbur- } \\
\text { dening my mother because we have no other support" (I7; } \\
\text { May, 2017) }\end{array}$ \\
\hline
\end{tabular}

"But she doesn't want to go anywhere. Whenever she's better, she tells me not to put her anywhere because she won't go" (I2; January, 2017)

"I know that at the beginning when I needed her she was there for me so now I have to give back and support my mother" (I8; July, 2017)

Relationship of proximity 56 "if she still communicated I could try, because it was easier, despite the difficulties, it was easier if she communicated and told me I want this, I want that, please give me this or I'm not feeling well, but it's difficult because she doesn't communicate anymore, knowing if she wants something or not, even if she wants anything at all" (I12; July, 2017)

"as long as I'm healthy, [he or she] is staying with me, period.” (I15; October, 2017 )

"If she's discharged home, I can't put her in the nursing home, it costs 850 Euros plus other expenses, I can't, and I want her near me" (I2; January, 2017 )

Economic issues $\quad 2 \quad 3$ "Some time ago, I spoke to the Technical Director of the nursing home and she mentioned 1,100 or 1,200 Euros, so how am I going to get by? I want to but I can't, I just can't" (I5; May, 2017)

"if it were just me, his daughter, I would take him to my place, I had no problem with it. . I'm not taking him home only because of my brothers, because I'd rather walk $2 \mathrm{~km}$ that way and $2 \mathrm{Km}$ this way, because I don't know if someFamily issues $\quad 3 \quad 3$ day they will say that I'm keeping his pension and that I have to take care of him by myself because he's living with me" (I4; March, 2017)

"I can't, if I lived alone with my husband...but I have two children"(I6; May, 2017)

\section{Discussion}

The interviewees' profile matches the one found in the literature (Sequeira, 2010): an average age of 58 years, mostly women, with a strong affective relationship to the person with dementia, spouse or daughters, with most of them being retired or homemakers, which was one 
of the factors facilitating the assumption of the caregiver role.

Many of the caregivers were still uncertain about their decision on the living arrangements after discharge from the UCCI, which confirms the results of other studies, particularly Tobias (2017) who reported distress and uncertainty as being the most common feelings among the families of RNCCI users from the perspective of social workers.

After discharge from the UCCI, the majority of informal caregivers of people living with dementia would place their family members in a residential facility for older people, indicating the environmental factors as the main reasons for this decision due to the poor housing conditions where the patient could move around. Healthcare increasingly recognize the importance of the physical world, as can be seen in the latest National Functionality Table for Adults and Older People (Direção-Geral da Saúde, 2019) which recommends that healthcare professionals should identify the environmental factor which can positively or negatively affect the performance of and participation in each of the activities under analysis at the level of functionality.

Some participants also mentioned the economic issues, which is in line with the results of Carvalho (2016) and Tobias (2017), who also reported the financial problems as one of the challenges of informal caregivers of patients admitted to the UCCI. In this study with caregivers of people with dementia, this issue is even more critical because a person with dementia in a residential facility can be 1.2 times more expensive than a person without dementia (Caravau, 2013).

More subjective aspects associated with the relationship of proximity, the caregiver unavailability, and family issues call attention to the potential importance of certain aspects of the caregiver's perspective, feelings, and relationships. Other authors had already recommended that they should be considered as they can even have a more significant influence on the decision of post-discharge destination than the patient's functional capacity (Tobias, 2017).

It is true that more individualized and regular home support services, strengthening a relationship of proximity and help between the person with dementia and the informal/formal caregivers, as well as economic support could promote the return home of the person with dementia. Mockford (2015) reinforces the need to develop customized and person-centered services, highlighting that, in preparation for hospital discharge, there is dissatisfaction with the available information and the management of conditions, mainly due to the little time to prepare and the insufficient communication with family members regarding services. The author also alerts to the lack of support services after discharge for caregivers who need help negotiating and managing their availability. Positive practices, such as the psychoeducational approaches, could help in this situation. Figueiredo, Guerra, Marques, and Sousa (2012) demonstrate that this type of intervention meets the caregivers' educational and support needs, allowing, on the one hand, the facilitation of knowledge and strategies for specialized care in dementia and, on the other hand, the creation or strengthening of social bonds between those who provide care. These bonds are of extreme importance because they allow sharing experiences and further developing key competencies for care delivery. Marques, Teixeira, and Souza (2012) underline the importance of training, which has proven to be beneficial for informal caregivers to acquire new knowledge about the diseases and practical strategies to improve care delivery. Tobias (2017) highlights the information/integration, the psychosocial care, and the work with partner institutions of the RNCCI (e.g., Social Security, private institutions of social solidarity, healthcare centers, city councils, and parish councils) in the adaptation to the new situation and satisfaction of needs.

The interpretation of the results found in this study should take into account the limitations related to transferability because the convenience sample is limited to two Portuguese districts where the caregivers' personal, family, and social characteristics can be different from those of other caregivers in other regions. With regard to the confirmation of credibility, although the analysis of the interviews was reviewed by an external researcher, the participants did not review it. This strategy could have confirmed if the researcher's interpretations reflect their experiences/thoughts/feelings. 


\section{Conclusion}

The experience of being an informal caregiver for a person with dementia is associated with a range of needs and challenges which do not end when the person is admitted to a long-term care unit. By examining the decision of family caregivers of people with dementia admitted to a UCCI regarding their discharge and the factors influencing this decision, this study can contribute to the identification of constraints and facilitators in the support provided to these families.

The feelings of fear and uncertainty reported by the majority of the participants and the high number of caregivers who considered institutionalization alert to the need for innovative and harmonized strategies to empower informal caregivers and help people with dementia stay in the community. Training, information, support, and more individualized services focused on people living with dementia and their caregivers should be part of the routine care of healthcare and social support institutions. Thus, future studies should further explore this topic in order to identify guidelines that contribute to the creation of intervention programs with informal caregivers focused on the promotion of knowledge and skills for care delivery. Moreover, strategies for the prevention of stress and overload situations should also be designed and implemented to improve the quality of life of informal caregivers and, consequently, people with dementia.

\section{References}

Administração Central do Sistema de Saúde, ACSS. (2018). Monitorizaçáo da Rede Nacional de Cuidados Continuados Integrados. Retrieved from http://www. acss.min-saude.pt/wp-content/uploads/2016/07/ Relatorio-1-semestre-18-vFINAL-v2.pdf

Caravau, H. (2013). Custos diretos da demência em lar de idosos (Master's dissertation). Secção Autónoma de Ciências da Saúde da Universidade de Aveiro.

Carvalho, A. (2016). Internamento na Rede de Cuidados Continuados e o destino pós alta: importância da capacidade funcional do utente e as dificuldades do cuidador/ família (Master's dissertation). Faculdade de Medicina da Universidade de Coimbra.

Direção-Geral de Saúde (2019). Implementação da Ta- bela Nacional de Funcionalidade no Adulto e Idoso. Retrieved from https://www.dgs.pt/directrizes-da-dgs/ normas-e-circulares-normativas/norma-n-0012019de-25012019-pdf.aspx

Eloia, S., Oliveira, E., Lopes, M., Parente, J., Eloia S., \& Lima, D. (2018). Sobrecarga de cuidadores familiares de pessoas com transtornos mentais: análise dos serviços sociais. Ciência e Saúde Coletiva, 23(9), 3001-3011. http://dx.doi.org/10.1590/141381232018239.18252016.

Etters, L., Goodall, D., \& Harrison, B. (2008). Caregiver burden among dementia patient caregivers: a review of the literature. Journal of the American Academy of Nurse Practitioners, 20, 423-428.

Figueiredo, D., Guerra, S., Marques, A., \& Sousa, L. (2012). Apoio psicoeducativo a cuidadores familiares e formais de pessoas com demência. Revista Kairós, 15(1), 31-55. Retrieved from https://revistas.pucsp. br/kairos/article/view/12776/9267

Marques, M., Teixeira, H., \& Souza, D. (2012). Cuidadoras informais de Portugal: vivências do cuidar de idosos. Revista Trabalho, Educação e Saúde, 10(1), 147-159. http://dx.doi.org/10.1590/S198177462012000100009

Ministério da Saúde (2019). Relatório Anual: Acesso a Cuidados de Saúde nos Estabelecimentos do SNS e Entidades Convencionadas. Retrieved from https:// www.sns.gov.pt/wp-content/uploads/2019/09/Relatorio_Acesso_2018-v.final_.pdf

Ministério do Trabalho, Solidariedade e Segurança Social \& Ministério da Saúde (2016). Plano de desenvolvimento da RNCCI: 2016-2019. Retrieved from https:// www.sns.gov.pt/wp-content/uploads/2016/02/Plano-de-desenvolvimento-da-RNCCI.pdf

Mockford, C. (2015). A review of family carers' experiences of hospital discharge for people with dementia, and the rationale for involving service users in health research. Journal of Health Leadership, 7, 21-28. doi: 10.2147/JHL.S70020

Santana I. (2012). A doença de Alzheimer e outras demências: diagnóstico diferencial. In A. Castro-Caldas (Coord.), A doença de Alzheimer e outras demências em Portugal (pp. 61-82). Lousã: Lidel - Edições Técnicas.

Santana, I., Farinha, F., Freitas, S., Rodrigues, V., \& Carvalho, A. (2015). Epidemiologia da demência e da doença de Alzheimer em Portugal: Estimativas da prevalência e dos encargos financeiros com a medicação. Acta Médica Portuguesa, 28(2), 182-188. Retrieved from https://www.actamedicaportuguesa.com/revista/ index.php/amp/article/viewFile/6025/4295

Seeher, K., Low, L., Reppermund, S., \& Brodaty, H. (2013). Predictors and outcomes for caregivers of 
people with mild cognitive impairment: a systematic literature review. Alzheimers \& Dementia, 9(3), 346-355.

Sequeira, C. (2010). Cuidar de idosos com dependência física e mental. Lousâ: Lidel - Edições Técnicas.

Sörensen, S., Pinquart, M., \& Duberstein, P. (2002). How Effective Are Interventions With Caregivers? An Updated Meta-Analysis. The Gerontologist, 42(3), 356-372.

Tobias, G. (2017). O Serviço Social no apoio às famílias de utentes integrados na RNCCI: Configurando os Sentimentos, Vivências e Expetativas dos familiares na perspetiva dos Assistentes Sociais (Master's dissertation). Escola Superior de Saúde do Instituto Politécnico de Bragança.
Unidade de Missáo para os Cuidados Continuados Integrados (2007). Cuidados Continuados Saúde e Apoio Social. Orientaçôes Gerais de Abordagem Multidisciplinar e Humanização em Cuidados Continuados Integrados. Retrieved from http://www.rncci.min-saude. pt/NR/rdonlyres/E8D26484-AD8E-4C7F-93648641579A1FBF/8096/20070320UMCCIOrientacoes.pdf

United Nations (2017). World Population Ageing: highlights. Retrieved from https:/www.un.org/en/development/desa/population/publications/pdf/ageing/ WPA2017_Highlights.pdf

World Health Organization \& Alzheimer Disease International (2012). Dementia: a public health priority. Geneva: WHO. 
